\begin{tabular}{ll}
\hline JURNAL ILMIAH \\
STOK BINA GUNA MEDAN \\
Volume 7 Nomor 1; Maret 2019 \\
- a dis
\end{tabular}

\title{
KONTRIBUSI GAYA MENGAJAR RESIPROKAL TERHADAP HASIL BELAJAR RENANG GAYA BEBAS
}

\author{
Muhammad Syaleh ${ }^{1}$, Ade Evriansyah Lubis ${ }^{2}$, Boby Helmi ${ }^{3}$ \\ 1,2,3 Sekolah Tinggi Olahraga dan Kesehatan Bina Guna \\ Jl. Alumunium Raya, Medan, Sumatera Utara, 20241, Indonesia \\ lubisadee@gmail.com
}

\begin{abstract}
ABSTRAK
Penelitian ini bertujuan untuk meningkatan hasil belajar renang gaya bebas dalam mata kuliah Teori dan Praktek Renang I dengan menggunakan penerapan gaya mengajar resiprokal pada mahasiswa Program Studi Pendidikan Jasmani Kesehatan dan Rekreasi Sekolah Tinggi Olahraga dan Kesehatan (STOK) Bina Guna sebanyak 30 mahasiswa. Penelitian ini menggunakan metode Penelitian Tindakan (Action Research). Subyek dalam penelitian ini adalah mahasiswa Program Studi PendidikanJasmani Kesehatan dan Rekreasi Sekolah Tinggi Olahraga dan Kesehatan (STOK) Bina Guna kelas B Tahun 2018/2019. Penelitian ini dilakukan dengan tujuh kali pertemuan terdiri dari dua siklus, siklus pertama yang direalisasikan melalui tindakan sesuai rencana dan metode pembelajaran, hasilnya nilai ratarata mahasiswa dalam pembelajaran renang gaya bebas pada tes awal 60 atau 36.67\% mahasiswa yang tuntas, dan $63.34 \%$ mahasiswa yang tidak tuntas. Pada siklus I hasil rata-rata mahasiswa 70 atau $60 \%$ mahasiswa tuntas, dan $40 \%$ mahasiswa yang tidak tuntas. Pada siklus ke dua yang direalisasikan melalui tindakan hasil refleksi dari siklus I, hasilnya ratarata 80 atau $90 \%$ mahasiswa tuntas dan $10 \%$ mahasiswa yang tidak tuntas. Berdasarkan hasil penelitian dapat disimpulkan bahwa: (1) dengan penerapan gaya mengajar resiprokal hasil belajar renang gaya bebas meningkat, (2) dengan penerapan gaya mengajar resiprokal yang diterapkan melalui alat bantu pelampung dalam meningkatkan hasil belajar renang gaya bebas.
\end{abstract}

\section{Kata Kunci: Gaya Mengajar Resiprokal, Renang Gaya Bebas.}

\section{PENDAHULUAN}

Mata kuliah teori dan praktek renang adalah salah satu mata kuliah yang harus di tempuh oleh mahasiswa Program Studi Pendidikan Jasmani Kesehatan Dan Rekreasi Sekolah Tinggi Olahraga dan Kesehatan (STOK) BinaGuna. Sebagai bekal mahasiswa kelak dalam menyiapkan diri sebagai calon guru olahraga.

Dalam pelaksanaan perkuliahan dengan menerapkan metode pembelajaran, masih terdapat kekurangan dan diperlukan adanya perbaikan, khususnya pada perkuliahan renang, antara lain: kurangnya pendekatan dosen terhadap mahasiswa dalam proses perkuliahan, (2) kurangnya evaluasi hasil pembelajaran terhadap mahasiswa pada akhir kegiatan, (3) kurang jelasnya tujuan yang ingin dicapai dalam proses pembelajaran (4) kurang pahamnya dosen dalam metode yang akan digunakan dalam penyampaian materi. 
Berdasarkan pengamatan peneliti selama ini di Program Studi Pendidikan Jasmani Kesehatan dan Rekreasi Sekolah Tinggi Olahraga dan Kesehatan (STOK) BinaGuna, banyak sekali faktor-faktor yang menjadi penyebab mahasiswa kesulitan dalam memahami konsep renang gaya bebas tersebut, salah satu faktornya adalah kurangnya pertemuan dalam proses belajar mengajar, dimana untuk saat ini dalam satu minggu hanya ada satu kali pertemuan. Selain itu dengan satu kali pertemuan yang berdurasi waktu 100 menit akan membuat mahasiswa terlalu kelelahan yang membuat tingkat konsentrasinya pun akan turun dalam belajar. Mengingat bahwa mahasiswa yang mengambil mata kuliah renang I adalah mahasiswa baru, kita ketahui bahwa pada mahasiswa baru dalam kuliahnya banyak sekali mata kuliah yang diambil berbarengan dengan mata kuliah renang I, sehingga proses belajar mengajar yang sedang berlangsung tidak efektif dan efesien. Oleh karena itu untuk mengatasi halini semua dibutuhkan kreatifitas dan peran dosen dalam proses pembelajaran renang.

Kemampuan dosen memilih dan menyajikan materi pembelajaran ditentukan oleh kemampuan dan pengalamannya dalam pembelajaran. Berkaitan dengan itu, maka untuk melakukan proses pembelajaran renang gaya bebas, dipilih strategi belajar mengajar yang tepat dan mudah diterapkan kepada mahasiswa, sehingga konsep- konsep teknik renang gaya bebas dan gerak dasarnya dapat dikuasai dengan baik dan benar.

Dengan adanya pendekatan, strategi, metode dan berbagai gaya mengajar merupakan alternatif bagi pendidik untuk meningkatkan kemampuan menyelenggarakan pembelajaran yang akan dilihat dari hasil yang diperoleh mahasiswa baik kemampuan secara keterampilan dan perubahan perilaku menjadi lebih baik. Masalah tidak boleh dibiarkan berkelanjutan oleh karena itu diperlukan berbagai upaya yang dapat meningkatkan hasil belajar mahasiswa. Salah satu upaya meningkatkan hasil belajar renang gaya bebas dengan menggunakan gaya mengajar resiprokal. Strategi dalam mengajar merupakan faktor yang sangat penting untuk memperoleh hasil belajar yang baik, salah satunya karena keberhasilan dari proses dapat dipengaruhi oleh strategi pembelajaran. Alasan rasional menggunakan gaya mengajar resiprokal adalah karena gaya resiprokal memiliki karakteristik dapat mengaktifkan mahasiswa dan dosen dalam setiap kegiatan pembelajaran.

Dengan pendekatan gaya mengajar resiprokal diduga dapat meningkatkan penguasaan keterampilan teknik gerakan dalam renang gaya bebas, karena dengan gaya resiprokal ini mahasiswa diberikan kebebasan untuk saling membantu dan mengevaluasi dalam melakukan teknik gerakan renang gaya bebas tersebut, sehingga mahasiswa bisa lebih kreatif. 
Gaya mengajar resiprokal merupakan pengembangan dari gaya latihan yang telah ditingkatkan pelaksanaannya sehingga memperbesar hubungan sosial dengan teman, serta mengambil manfaat dari adanya umpan balik sesama teman sebaya.

Metode ini merupakan alternatif metode yang dapat dipilih dalam pengajaran renang, mengingat dalam pengajaran renang diperlukan suatu bentuk kegiatan yang dapat mengarahkan mahasiswa untuk dapat menemukan suatu konsep melalui praktek menguasai gerakan yang dipelajari atau penemuan secara langsung, penerapan gaya mengajar resiprokal pada pokok bahasan antara lain bertujuan agar mahasiswa mampu melakukan teknik renang gaya bebas serta meningkatkan hasil belajar mahasiswa.

Gaya bebas merupakan gerakan renang yang memiliki karakter gerakan yang sudah lazim dilakukan dalam kehidupan sehari-hari dan merupakan gerakan renang yang paling mendasar. Dengan demikian bahwa renang gaya bebas adalah merupakan gerakan renang yang paling efisien jika dibandingkan dengan gerakan lainnya karena teknik dari gerakan renang ini merupakan gerakan yang kita lakukan sehari-hari, dan badan dapat dengan maksimal mengarahkan seluruh kekuatan dengan kuat dan secara terus menerus dan dengan hambatan yang sangat sedikit dibandingkan dengan gaya renang yang lain.
Sedangkan Ernest W. Maglischo mengungkapkan bahwa gaya bebas merupakan gaya yang tercepat dan berdasarkan gaya ini pula kehebatan berenang akan dinilai bagaimana mulusnya dan mudahnya berenang gaya bebas. Didalam renang gaya bebas yang perlu kita pelajari yaitu bagaimana cara posisi tubuh di dalam air, gerakan kaki, gerakan tangan, bernafas dan gerakan koordinasi. Penjelasan rinci tentang masing-masing teknik dasar renang gaya bebas adalah sebagai berikut:

\section{- Posisi Tubuh (Body Position)}

Selama berenang gaya bebas, posisi badan harus senantiasa dalam posisi streamline atau tubuh harus bisa menyerupai balok kayu yang saat mengapung di air. Sehingga pada posisi streamline mulai dari ujung jari tangan samapai ujung jari kaki tubuh dapat berputar pada garis pusat atau pada rotasinya. Saat melakukan gerakan posisi kepala harus streamline dengan badan, telinga segaris dengan badan, tubuh harus keadaan posisi lurus, sejajar dengan permukaan air, kedua tangan lurus ke depan dan pandangan ke bawah usahakan lengan bersentuhan dengan daun telinga, dan kepala harus sejajar dengan badan.

\section{- Gerakan Kaki (Kicking)}

Gerakan kaki pada renang berguna untuk memberi dorongan maju dan megatur keseimbangan badan, sehingga badan dapat bergerak dalam keadaan stabil.Teknik gerakan kaki pada rennag gaya bebas yaitu 
sikap permulaan kedua lengan lurus kedepan, tubuh dan kedua kaki lurus ke belakang rata dengan permukaan air, kepala atau muka menghadap ke dasar kolam/kebawah dan gerakannya dimulai dari pinggul dan berakhir dengan kibasan pergelangan kaki, gerakan kaki yang ke bawah di lakukan agak kuat, terutama pergelangan kaki. Kedalaman tungkai kaki bagian bawah atau telapak kaki dari permukaan air ketika pemukulan dan lecutan sekitar 30-35 cm.

- Gerakan Rotasi Tangan (Hand Rotation)

Di dalam gerakan tangan mempunyai beberapa fase gerakan yaitu fase masuk permukaan air (Entry Phase), fase menangkap (Catch Phase), fase menarik (Pull Phase), fase mendorong (Push Phase), dan fase Istirahat (Recovery Phase).

- Gerakan Pengambilan Nafas (Breathing)

Pengambilan napas dalam renang gaya bebas dilakukan pada saat salah satu tangan berada di belakang atau sejajar dengan badan dan disaat itu bersamaan tolehkan kepala ke arah tangan yang lagi melakukan gerakan push sehingga kepala keluara dari permukaan air dan pada saat di atas permukaan air mulut atau hidung menghirup udara sebanyak mungkin, usahakan pada saat melakukan gerakan pengambilan napas daun telinga yang sebelahnya kena dengan lengan yang lagi melakukan gerakan entry agar kepala tidak terlalu naik ke atas permukaan air. Kepala segera dimasukkan kedalam air lagi dan keluarkan udara dari mulut, hal ini untuk menghindari masuknya air ke dalam hidung.

- Koordinasi renang gaya bebas

Sikap tubuh yang hampir sejajar dengan permukaan air, irama kaki yang telah kotinue naik turun, lengan kanan berada lurus di depan, sedangkan lengan kiri melakukan tarikan dengan sikap menyudut hingga tarikan ini di bawah pusat, ingat pandangan di dalam air tetap lurus kedepan. Setelah tarikan tangan kiri berakhir di bawah pusar kemudian disambung dengan dorongan tangan dari bawah pusar membelok ke samping bagian tubuh dan berakhir disamping paha.Tangan kiri hampir berakhir melakukan dorongan, tangan kanan bersiap untuk membuka selebar bahu bertepatan dengan tangan kiri berakhir di paha, maka tangan kanan mulai bergerak meraih air yang selanjutnya membentuk sudut dibawah paha, kemudian tangan kiri melakukan recovery dengan mengankat siku, serentak tangan kanan mengakhiri tarikan hingga dibawah pusar. Saat tangan kiri melakukan entry selesai maka dorongan tangan kananpun selesai dengan berakhir di samping paha, serentak melakukan dorongan pada saat itu lakukanlah gerakan mengambil napas kesamping kanan. Setelah berakhir dorongan tangan ke kanan serta berakhirnya pengambilan udara di permukaan air, siku mulai diangkat 
kemudian dibawa mendekati telinga, dengan diikuti oleh pandangan mata sampai tangan kanan melakukan entry, leher/kepal diputar masuk kepermukaan air untuk membuang udara.

$$
\text { Gaya belajar merupakan }
$$

kepribadian atau personaliti kesanggupan mahasiswa untuk terlibat dalam proses belajar, sedangkan gaya mengajar merupakan interaksi yang dilakukan oleh guru dengan mahasiswa dalam proses belajar mengajar agar materi yang disajikannya dapat di serap oleh mahasiswa. Gaya mengajar resiprokal merupakan gaya timbal balik ataufeed back.

Dalam hal ini mahasiswa diberikan kebebasan untuk membuat keputusan sehubungan dengan pelaksanaan tugas. mahasiswa diberikan kewajiban untuk memiliki hasil belajar secara terbatas. Penilaian hanya terbatas pada penilaian formatif atau korelatif oleh seorang mahasiswa terhadap seorang mahasiswa terhadap hasil belajar.Namun yang paling umum ialah seorang mahasiswa atau sering diterapkan dalam formasi berpasangan.

Menurut Mosston mengatakan bahwa gaya resiprokal yaitu memperhatikan perubahan yang lebih besar dalam membuat keputusan dari guru kepada mahasiswa. Mahasiswa bertanggung jawab untuk mengobservasi penampilan atau pasangannnya dan memberi umpan balik segera pada setiap kal melakukan gerakan. Guru mempersiapkan lembar tugas yang menjelaskan tugas yang harus dilakukan, kriteria evaluasi berfungsi untuk menentukan bahwa gerakan yang harus dilakukan oleh pasangannya itu sudah sesuai dengan rujukan.

Dari penjelasan di atas, dapat disimpulkan bahwa gaya mengajar resiprokal pada saat guru memberi pelajaran terlebih dahulu mendemonstrasikan dan menguraikan cara pelaksanaannya. Kemudian guru memberikan lembar tugas yang menjelaskan kriteria evaluasi sebagai penentu gerakan yang harus dilakukan. Mahasiswa diatur berpasangan yang satu berperan sebagai pelaku dan yang lain sebagai pengamat. setelah itu pelaku melakukan apa yang tertera pada lembar tugas dan pengamat memberikan komentar mengenai apa yang dibuat pelaku.

Dalam hal ini Adisasmita, yang menyatakan bahwa dalam gaya pembelajaran resiprokal, tanggung jawab memberikan umpan balik bergeser dari guru kepada teman sebaya. Pergeseran peranan ini memungkinkan terjadinya peningkatan interaksi sosial antara teman sebaya dan pemberian umpan balik secara langsung.

Dalam gaya pembelajaran resiprokal, setiap mahasiswa memberikan umpan balik terhadap mahasiswa lainnya. Seorang mahasiswa bertindak sebagai pelaku atau pelaksana tugas gerak sementara mahasiswa pasangannya bertindak sebagai pengamat (observer) 
serta menyiapkan umpan balik, selanjutnya berganti peran. Adapun dosen bertanggung jawab dalam membuat keputusan tentang tugas apa yang harus dilakukan, mendesain kriteria sebagai petunjuk (guide) bagi pengamat dalammemberikan umpan balik, memberikan tugas kepada mahasiswa dan membantu pengamat meningkatkan kemampuannya untuk berkomunikasi dengan pasangannya.Landasan teori dari gaya pembelajaran resiprokal, pada dasarnya menerapkan teori umpan balik. Teori ini beranggapan bahwa informasi tentang keterampilan akan memantapkan atau memperbaiki hasil belajarnya di kemudian hari. Informasi yang menyebabkan perbaikan disebut umpan balik negatif sedangkan informasi yang justru memantapkan keterampilannya disebut umpan balik positif.

Proses pendidikan kegiatan belajar dan pembelajaran merupakan suatu usaha yang amat strategis untuk mencapai tujuan yang diharapkan. Pergaulan yang bersifat mendidik itu terjadi melalui interaksi aktif antara mahasiswa sebagai peserta didik dan guru sebagai pendidik. Kegiatan belajar dilakukan oleh mahasiswa dan melalui kegiatan ituakan ada perubahan perilakunya sementara kegiatan pembelajaran dilakukan oleh guru untuk memfasilitasi proses belajar kedua peranan itu tidak terlepas dari situasi saling mempengaruhi dalam pola hubungan antara dua subjek.

Seseorang yang telah berhasil dalam belajar adalah bila ia mengalami perubahan tingkah lakunya jika dibandingkan pada keadaan sebelumnya. Tentu saja hal ini dapat dengan usaha latihan yang harus dilakukan dengan sungguh-sungguh dan semangat yang tinggi serta dilakukan dengan sadar sehingga menjadi terbiasa. Dari pendapat di atas dapat disimpulkan bahwa faktor- faktor yang mempengaruhi hasil belajar mahasiswa adalah faktor internal mahasiswa antara lain kemampuan yang dimiliki mahasiswa tentang materi yang akan disampaikan.

\section{METODE PENELITIAN}

Penelitian tindakan merupakan suatu penelitian yang penting untuk dilaksanakan dalam pendidikan dengan maksud untuk meningkatkan praktik yang diselenggarakan, dalam pembelajaran. Kemmis dan Mc Taggart menyatakan bahwa penelitian tindakan adalah suatu bentuk reflektif diri yang dilakukan dengan partisipan dalam situasi sosial atau praktek pendidikan.

Penelitian tindakan diawali oleh suatu kajian terhadap suatu masalah secara sistematis.Hasil kajian ini dijadikan dasar untuk menyusun suatu rencana kerja (tindakan) sebagai upaya untuk mengatasi masalah tersebut. Kegiatan berikutnya adalah pelaksanaan tindakan dilanjutkan dengan observasi dan evaluasi. Hasil observasi dan evaluasi digunakan sebagai masukkan melakukan refleksi atas apa yang terjadi pada saat pelaksanaan tindakan. Hasil refleksi kemudian dijadikan landasan 
untuk menentukan perbaikan serta penyempurnaan tindakan selanjutnya.

Menurut Carr dan Kemmis seperti yang dikutip Siswojo Harjodipuro bahwa penelitian tindakan adalah suatu bentuk refleksi diri yang dilakukan oleh para partisipasi guru, mahasiswa atau kepala sekolah dalam situasi-situasi sosial termasuk pendidikan untuk memberiakan rasionalitas kebenaran (a) praktik-praktik sosial atau pendidikan yang dilakukan sendiri. (b) pengertian mengenai praktikpraktik ini, dan (c) situasi-situasi tempat praktik-praktik tersebut dilaksanakan.

Berdasarkan pendapat di atas, maka dapat disimpulkan bahwa penelitian tindakan merupakan penerapan penemuan fakta untuk pemecahan masalah dalam situasi sosial dengan tujuan meningkatkan kulalitas tindkan yang dilakukan, penelitian tindakan dapat dilakukan sendiri maupun berkolaborasi antara peneliti dan praktisi, penelitian tindakan merupakan perpaduan antara penelitian kualitatif dan kuantitatif, sehingga memiliki kedua jenis data tersebut, dalam prosesnya, penelitian tindakan menyerupai eksperimen, hanya tanpa sampling dan tanpa kontrol ketat sebagaimana dalam eksperimen, sehingga dapat dikategorikan sebagai eksperimen lemah. Sedangkan menurut Sukardi penelitian tindakan adalah cara suatu kelompok atau seseorang dalam mengorganisasi sebuah kondisi dimana mereka dapat mempelajari pengalaman mereka dan membuat pengalaman mereka dapat diaskes oleh orang lain. Selain itu kelas adalah tempat para guru melakukan penelitian, dengan dimungkinkan mereka tetap bekerja sebagai guru di tempat kerjanya.

Dari penjelasan tersebut di atas dapat disimpulkan bahwa, penelitian tindakan adalah cara suatu kelompok atau seseorang dalam mengorganisasi suatu kondisi sehingga mereka dapat mempelajari pengalaman mereka dan membuat pengalaman mereka dapat diakses oleh orang lain.

Berdasarkan latar belakang penelitian yang telah diuraikan, maka penelitian ini bertujuan untuk meningkatkan hasil belajar renang gaya bebas pada mahasiswa Program Studi PendidikanJasmani Kesehatan dan Rekreasi Sekolah Tinggi Olahraga dan Kesehatan (STOK) Bina Guna kelas B Tahun 2018/2019 melalui penerapan gaya mengajar resiprokal dengan menggunakan alat bantu pull boy dan pelampung.

Penelitian ini dilaksanakan dikolam renang Tirta Kartika Medan pada mahasiswa yang mengambil mata kuliah Teori dan Praktek Renang I. Waktu pelaksanaan penelitian pada awal bulan Februari sampai April 2019 dengan frekuensi penelitian adalah tujuh kali pertemuan satu minggu sekali dengan bulan pertama sebagai pelaksanaan penelitian di lapangan dilanjutkan dengan pengolahan data dan analisis data pada bulan berikutnya. 
Subyek penelitian dalam penelitian peningkatan pembelajaran renang gaya bebas melalui penerapan gaya mengajar resiprokal adalah mahasiswa Program Studi PendidikanJasmani Kesehatan dan Rekreasi Sekolah Tinggi Olahraga dan Kesehatan (STOK) Bina Guna kelas B Tahun 2018/2019 yang berjumlah 30 mahasiswa.

Analisis data dalam penilaian ini adalah deskriptif kualitatif dan kuantitatif, data kualitatif membandingkan data tes awal dan hasil tes setelah siklus 1 dan 2 . Sedangkan kuantitatif adalah refleksi dalam setiap siklusnya berdasarkan hasil observasi yang terekam dalam catatan lapangan, dokumentasi, dan observasi. Analisis data dilakukan secara deskriptif dengan membandingkan hasil pencapaian dengan indikator keberhasilan.

\section{HASIL DAN PEMBAHASAN}

Berdasarkan perolehan data pada tes awal dalam renang gaya bebas maka dapat disimpulkan bahwa sebanyak 11 mahasiswa yang tuntas atau sekitar $36.67 \%$ dengan batas minimal $70 \mathrm{KKM}$ dari 30 mahasiswa. Sedangkan mahasiswa yang tidak tuntas berjumlah 19 mahasiswa atau sekitar $63.4 \%$.

Dari hasil pengamatan awal dan wawancara dengan dosen renang I di Program Studi Pendidikan Jasmani Kesehatan dan Rekreasi Sekolah Tinggi Olahraga dan Kesehatan (STOK) Bina Guna kelas B Tahun 2018/2019 diperoleh informasi bahwa pelaksanaan pembelajaran khususnya renang gaya bebas melalui kegiatan belajar sebelumnya telah dilaksanakan oleh dosen, namun belum sepenuhnya efektif. Metode pembelajaran yang diterapkan masih bersifat satu arah.

Pengamatan dilakukan oleh peneliti dan kolabolator diantaranya menggunakan camera. Dari pengamatan ini dihasilkan catatan lapangan (CL). Hasil pengamatan catatan lapangan tentang penerapangaya mengajar resiprokal dengan pembelajaran renang gaya bebas yang tadinya membosankan berubah menjadi menyenangkan. Interaksi sesama teman terjalin dengan baik karena terjadi umpan baik secara langsung sehingga proses pembelajaran menjadi lebih aktif.

Berdasarkan pengamatan observer diperoleh pada saat tes siklus I dilakukan ada beberapa mahasiswa yang melakukan kesalahan, yaitu pada saat melakukan gerakan kaki terlihat beberapa mahasiswa pada saat melakukan renang gaya bebas kaki masih sedikit tenggelam tidak sejajar dengan badan dan pada saat pengambilan nafas terlihat kepala masih terangkat, juga pada saat gerakan koordinasi mahasiswa masih takut dan belum mampu melakukan renang gaya bebas dengan jarak 50 meter.

Berdasarkan perolehan data pada siklus I maka dapat disimpulkan bahwa sebanyak 18 mahasiswa yang tuntas atau sekitar 60\% dengan batas minimal KKM 70 dari 30 mahasiswa. Sedangkan mahasiswa yang tidak tuntas sekitar 12 mahasiswa atau sekitar $40 \%$. 
Sementara data kuantitatif yang diperoleh pada siklus I bahwa mahasiswa yang tuntas sekitar 11 mahasiswa atau sekitar $36.67 \%$ dengan batas minimal 70 KKM dari 30 mahasiswa.Sedangkan mahasiswa yang tidak tuntas sekitar 19 mahasiswa atau sekitar $63.4 \%$. pada siklus yang pertama ini belum dikatakan berhasil karena jumlah mahasiswa yang tuntas tidak mencapai $80 \%$ dari keseluruhannya, dilanjut kesiklus II dimana telah diberi tindakan dengan hasil mahasiswa yang tuntas sekitar 90\% sebanyak 27 orang mahasiswa dan sekitar 10\% mahasiswa yang tidak tuntas sebanyak 3 orang.

Pengamatan dilakukan oleh peneliti dengan menggunakan camera. Dari pengamatan dihasilkan catatan lapangan (CL). Hasil pengamatan catatan lapangan tentang penerapan gaya mengajar resiprokal untuk meningkatkan hasil belajar renang gaya bebasdengan membentuk kelompok kecil yang masing-masing kelompok berjumlah 3 orang. 1) masingmasing mahasiswa dalam kelompok mendapat tugas sebagai pengamat, pelaku dan pembantu, tugas seorang pembantu yaitu sebagai pengganti penggunaan alat bantu. 2) melakukan perlombaan renang gaya bebas 50 meter dengan peraturan yang sudah dimodifikasi.

Berdasarkan perolehan data pada siklus II maka dapat disimpulkan bahwa sebanyak 27 mahasiswa yang tuntas atau sekitar $90 \%$ dengan batas minimal $70 \mathrm{KKM}$ dari 30 mahasiswa. Sedangkan mahasiswa yang tidak tuntas sekitar 3 mahasiswa atau sekitar $10 \%$.

Dipertemuan yang terakhir ini mahasiswa tampaknya sudah banyak perubahan dan kemajuan dimana mahasiswa telah mengaplikasikan gaya mengajar resiprokal dalam pembelajaran renang gaya bebas. Bentuk pengamatan dalam interaksi timbal balik dan mahasiswa tidak lagi ragu-ragu untuk melakukan gerakan kaki, pengambilan nafas serta gerakan koordinasi renang gaya bebas, terlihat banyak kemajuan yang telah dialami mahasiswa.

Dan secara keseluruhan mahasiswa dan dosen melakukan pembelajaran dengan baik dan benar terbukti mahasiswa dapat mengaplikasikan gerakan koordinasi tersebut di praktek renang gaya bebas 50 meter dengan hasil belajar yang memuaskan dimana secara klasikal 90\% telah tuntas melebihi target yang dicapai.

\section{KESIMPULAN}

Berdasarkan hasil penelitian yang telah dipaparkan, secara umum dapat disimpulkan bahwa adanya peningkatan hasil belajar mahasiswa melalui gaya mengajar resiprokal pada mata kuliah renang I renang gaya bebas pada mahasiswa Program Studi Pendidikan Jasmani Kesehatan dan Rekreasi Sekolah Tinggi Olahraga dan Kesehatan (STOK) Bina Guna kelas B Tahun 2018/2019. Pada siklus I mahasiswa cukup antusias dalam mengikuti mata kuliah renang gaya bebas. 
Sesuai dengan refleksi, nilai rata-rata kelas pada mata kuliah renang gaya bebas adalah 70 dengan persentase ketuntasan 60\% mahasiswa yang lulus dan hasil belajar siswa pada siklus kedua adalah 80 dengan persentase ketuntasan $90 \%$ dapat disimpulkan adanya peningkatan yang signifikan hasil belajar pada siklus II. Dengan penerapan gaya mengajar resiprokal yang telah peneliti rancang yaitu dengan berpasangan dan media alat bantu berupa pull boy dan pelampung sesuai dengan kebutuhan mahasiswa untuk meningkatkan hasil belajar renang gaya bebas, mahasiswa lebih aktif dalam mengikuti proses pembelajaran, sehingga dapat diperoleh hasil yang optimal dalam penguasaan materi perkuliahan khususnya renang gaya bebas.

\section{DAFTAR PUSTAKA}

Adisasmita, Yusuf. (1997). Strategi Instruksional Pendidikan Jasmani dan Olahraga. Jakarta: PPs IKIP Jakarta.

Kemmis, Stephen. Robbin, McTaggart. (1988). The Action Research Planner. $3 r d$ ed. Victoris Deakin University.

Madya, Suwarsih. (2006). Penelitian Tindakan. Bandung: CV. Alfabeta Bandung.

Maglischo, Ernest. W. (2003). Swimming Fastest. Canada: Human Kinetics.

Mosston, Muska. (2000). Teaching Physical Education. Columbus: Charles E and Merril Publishing Company.

Sukardi. (2013). Metode Penelitian Pendidikan Tindakan Kelas. Jakarta: PT Bumi Aksara.

Thomas, David G. (1996). Renang Tingkat Pemula. Jakarta: PT Raja Grafindo Persada. 